\title{
Development and Validation of New Analytical Method for the Estimation of Beclomethasone Dipropionate, Clotrimazole and Neomycin Sulphate in Bulk and Pharmaceutical Dosage Forms
}

\author{
M. Sathwik, P. Vijay Sai Raghav, A. Shanta Kumari *, Sk. Abdul Rahaman \\ Department of Pharmaceutical Analysis, Nirmala College of Pharmacy, Mangalagiri, Guntur, Andhra Pradesh, India
}

\begin{abstract}
Address for
Correspondance

A. Shanta Kumari,

Skatakam9@g

$\underline{\text { mail.com }}$
\end{abstract}

\begin{abstract}
A new simple, precise, accurate, economic and selective HPLC method has been developed and validated for the estimation of Beclomethasone dipropionate, Clotrimazole, and Neomycin sulphate in bulk and Pharmaceutical dosage form. Column is Zorbax C18 $150 \times 4.6 \mathrm{~mm}, 5 \mu \mathrm{m}$, wave length $239 \mathrm{~nm}$, injection volume $20 \mu \mathrm{L}$, column temperature is ambient and flow rate $1.0 \mathrm{~mL} / \mathrm{min}$. Retension time of clotrimazole, neomycin sulphate, beclomethasone dipropionate is about 2.209, 4.7 and 8.4 min respectively and also estimated by uv-visible spectrophotometry the solvent is $0.1 \mathrm{~N} \mathrm{NaoH}$, wave length is $421 \mathrm{~nm}$, linearity is $2-10 \mu \mathrm{g} / \mathrm{mL}$. The developed methods have been validated statistically as per ICH guidelines. The method showed good reproducibility and recovery with \%RSD less than 2 . So, the proposed methods were found to be simple, specific, precise, accurate and linear. Hence it can be applied for routine analysis of Beclomethasone dipropionate, Clotrimazole, Neomycin sulphate in bulk drug and Pharmaceutical preparations. (C) 2018 iGlobal Research and Publishing Foundation. All rights reserved.
\end{abstract}

Received:

20.03.2018

Accepted:

21.05.2018

Cite this article as: Sathwik, M.; Raghav, P.V.S.; Kumari, A.S.; Rahaman, Sk.A. Development and validation of new analytical method for the estimation of beclomethasone dipropionate, clotrimazole and neomycin sulphate in bulk and pharmaceutical dosage forms. Indo Global Journal of Pharmaceutical Sciences, 2018; 8(3): 88-91.

Keywords Beclomethasone dipropionate; Clotrimazole; Neomycinsulphate; RP-HPLC; Validation; C-18 column.

\section{INTRODUCTION}

HPLC is an analytical technique used to separate, identify and quantify the component. It finds its use for research, manufacturing, medical, legal purposes. The development of an analytical method for the identification and quantification of drugs by HPLC has received considerable attention in recent years because of their importance in quality control of drugs and drug products. In the present study attempt is made to estimate the following three drugs simultaneously.

Beclomethasone dipropionate IUPAC name 2-[(1R, 2S, 10S, 11S, 13S, 14R, 15S, 17S)-1-chloro-17-hydroxy-2, 13, 15trimethyl-5-oxo-14-(propanoyloxy)tetracyclo[8.7.0.0 2 ,

$7\} .0\{11,15\}]$ heptadeca-3, 6-dien-14-yl]-2- oxoethylpropionate. It is soluble in methanol; sparingly soluble in ethanol; slightly soluble in ethyl acetate, dichloromethane and acetonitrile; It is used for the prophylaxis of asthma It is used for the treatment of rhinitis(e.g. hay fever). It acts as a anti-inflammatory, and it is a synthetic corticosteroid.

Clotrimazole IUPAC name 1-[(2chlorophenyl)diphenylmethyl]-1H-imidazole It is soluble in DMSO $(25 \mathrm{mM})$, chloroform $(50 \mathrm{mg} / \mathrm{mL})$, DMF, ethyl acetate, ethanol, It is an anti-fungal agent, 14-alpha demethylase inhibitor and anti-infective agent.

Neomycin sulphate IUPAC name (2R, 3S, 4R, 5R, 6R)-5amino-2-(aminomethyl)-6- $\{[(1 \mathrm{R}, 2 \mathrm{R}, 3 \mathrm{~S}, 4 \mathrm{R}, 6 \mathrm{~S})-4,6-$ diamino-2-\{[(2S, 3R, 4S, 5R $)-4-\{[(2 R, 3 R, 4 R, 5 S, 6 S)-3-$ 


\section{Indo Global Journal of Pharmaceutical Sciences, 2018; 8(3): 88-91}

amino-6-(aminomethyl)-4, 5- dihydroxyoxan-2-yl]oxy\}-3hydroxy 5 (hydroxymethyl)oxolan-2-yl]oxy\}-3hydroxycyclohexyl]oxy oxane-3, 4-diol. It is a yellow colour powdered form and soluble in $\mathrm{NaOH}$, ethanol $(0.10 \mathrm{mg} / \mathrm{ml})$, methanol $(0.23 \mathrm{mg} / \mathrm{mL})$, isopropanol $(0.08 \mathrm{mg} / \mathrm{mL})$, isoamyl alcohol $(0.25 \mathrm{mg} / \mathrm{mL})$ and benzene $(0.05 \mathrm{mg} / \mathrm{mL})$. It is insoluble in acetone, chloroform and ether. It belongs to bactericidal aminoglycoside antibiotic and it is used as aminoglycoside antibiotic found in many topical medications such as creams, ointments and eyedrops.

\section{MATERIALS AND METHODS}

\section{Chemicals}

Beclomethasone dipropionate, Clotrimazole and Neomycin sulphate pure drugs procured from Nirmala college of Pharmacy, Atmakuru, Guntur district. HPLC grade Acetonitrile, HPLC grade Water were purchased from Merck (India) Ltd., Mumbai, India. All other chemicals are of analytical grade from S.D.Fine Chemical Ltd., Worli, India. Ointment (QUADRI DERM) was purchased from Indian market, containing beclomethasone dipropionate $(0.025 \mathrm{mg})$, clotrimazole $(1 \mathrm{mg})$ and neomycin sulphate $(0.5 \mathrm{mg})$ manufactured by fulford india ltd.

\section{Instrumentation}

Analysis was performed on HPLC instrument equipped with UV detector, Rheodyne injector and C-18 column compartment with EX1600SM soft ware (Cyber Lab corporation, USA.) Other equipments used in the study were, UV-Visible Spectrophotometer (Evolution-201;Thermo Scientific, India) and ultrasonic bath (Amkette Industries India).

\section{Method development \\ Preparation of Standard solution for Beclomethasone Dipropionate clotrimazole, neomycin sulphate}

Accurately weighed equal amounts $50 \mathrm{mg}$ of beclomethasone, clotrimazole, neomycin sulphate working standards were transferred into three $100 \mathrm{~mL}$ volumetric flasks. $70 \mathrm{~mL}$ of diluents is added to each flask, sonicated and made up the volume to100 $\mathrm{mL}$ with diluent. Further dilutions of each drug was $0.1 \mathrm{~mL}$ to $100 \mathrm{~mL}$ with the diluents.

\section{Chromatographic conditions}

Zorbax C18 Column $(250 \mathrm{~mm}$ x $4.6 \mathrm{~mm}, 5 \mu \mathrm{m})$ was used for chromotographic separation. The mobile phase composed of acetonitrile and buffer (30:70) $\mathrm{v} / \mathrm{v}$; at a flow rate of $1.0 \mathrm{ml} / \mathrm{min}$ with run time of $10 \mathrm{~min}$. Mobile phase and sample solutions were filtered through a $0.45 \mu$ nylon syringe filter (Millipore, USA) and degassed. The detection of three drugs was carried out at $239 \mathrm{~nm}$ (Isoabsorptive point).

\section{Analysis of marketed ointment (QUADRI DERM)}

A $100 \mathrm{mg}$ cream equivalent to the label claim of the drugs of sample is weighed into a $500 \mathrm{~mL}$ volumetric flask. $100 \mathrm{~mL}$ of diluent is added, sonicated to dissolve and made up to volume with diluent. Further diluted 0.5 to $100 \mathrm{~mL}$ with the diluent. Filtered through $0.45 \mu$ Nylon syringe filter. Injected $20 \mu \mathrm{L}$ of Standard preparation five times and Sample preparation into the Chromatographic column. The chromatograms are recorded and the peak responses for Clotrimazole, Beclomethasone dipropionate and Neomycin sulphate are measured. The System suitability parameters are met. From the peak responses, the content of Clotrimazole, Beclomethasone and Neomycin in the sample are calculated.

Assay calculations
\begin{tabular}{|l|l|l|l|}
\hline Drug & $\begin{array}{l}\text { Labeled } \\
\text { amount(m } \\
\text { g) }\end{array}$ & $\begin{array}{l}\text { Amount } \\
\text { present(m } \\
\text { g) }\end{array}$ & $\begin{array}{l}\text { \% } \\
\text { Assa } \\
\text { y }\end{array}$ \\
\hline $\begin{array}{l}\text { Beclomethaso } \\
\text { ne } \\
\text { Dipropionate }\end{array}$ & 0.025 & 1.07 & 100.7 \\
\hline Clotrimazole & 1 & 1.02 & 100.2 \\
\hline $\begin{array}{l}\text { Neomycin } \\
\text { Sulphate }\end{array}$ & 0.5 & 0.504 & 100.4 \\
\hline
\end{tabular}

\section{Validation of method}

The HPLC method was validated in accordance with ICH guidelines. The linearity of detector response for beclomethasone, clotrimazole, neomycin sulphate was established for five concentrations. The final concentrations of each solution in $\mu \mathrm{g} / \mathrm{mLwas}$ calculated and plotted against area response. The slope, y-intercept, correlation coeffiecient were calculated. System precision of the method was verified by six injections from the same standard preparations were made and the relative standard deviation for the replicate injections was calculated. The method precision was carried out the six times using the proposed method. Repeatability was measured by multiple injections of a homogenous sample of beclomethasone, dipropionate, clotrimazole, neomycin sulphate. Accuracy was conducted for Beclomethasone dipropionate, Clotrimazole, Neomycin sulphate.Assay in triplicate $(50 \%, 100 \%$ and $150 \%)$ as per test equivalent of drugs containing beclomethasone, dipropionate clotrimazole, neomycin sulphate into each volumetric flasks for each spike level to get concentration of these three drug solutions equivalent to $50 \%, 100 \%$, and $150 \%$ of the labeled amount as per test method. The average \% recovery was calculated.Solution stability of beclomethasone dipropionate, Clotrimazole, neomycin sulphate in diluents was detrmined by storing sample solution (30ppm) in a tightly closed in volumetric flask at room temperature for $24 \mathrm{~h}$. later these drug solutions measured at different time interval like 4, 12, and 24 hrs and finally result is obtained were compared with freshly prepared solutions. Robustness was evaluated by analysis of aliquots from homogenous lots by different physical parameters like flow rate, mobile phase composition, wave length which may differ but the response still within the specified limits of assay.

\section{RESULTS AND DISSCUSSION}

HPLC is an analytical technique used to separate, identify and quantify the component. It finds its use for research, manufacturing, medical, legal purposes. The development of an analytical method for the identification and quantification of drugs by HPLC has received considerable attention in 


\section{Indo Global Journal of Pharmaceutical Sciences, 2018; 8(3): 88-91}

recent years because of their importance in quality control of drugs and drug products. The objective of the present study was to develop a simple, rapid, precise, accurate and sensitive HPLC method for the analysis of Beclomethasone Dipropionate, Clotrimazole, Neomycin Sulphate in bulk and its pharmaceutical dosage form by using solvent system of ACN: OPA in the ratio 70:30 and Kromasil C18, $150 \mathrm{~mm} \mathrm{x}$ $4.6 \mathrm{~mm}, 5 \mu \mathrm{m}$ stationary phase. The chromatographic condition is optimized at flow rate of $1 \mathrm{ml} / \mathrm{min}$ with UV detection at 239 $\mathrm{nm}$. Validation studies are carried out by using freshly prepared solutions as per ICH requirements.

\begin{tabular}{|c|c|c|c|}
\hline Parameter & $\begin{array}{l}\text { Beclomethasone } \\
\text { dipropionate }\end{array}$ & Clotrimazole & $\begin{array}{l}\text { Neomycin } \\
\text { sulphate }\end{array}$ \\
\hline $\begin{array}{l}\text { Linearity } \\
\text { Range } \\
\text { correlation } \\
\text { coefficient }\end{array}$ & $\begin{array}{l}0.05-0.038 \mathrm{ppm} \\
\mathrm{R}^{2}=0.999\end{array}$ & $\begin{array}{l}0.200- \\
1.506 \mathrm{ppm} \\
\mathrm{R} 2=0.998\end{array}$ & $\begin{array}{l}0.100- \\
0.750 \mathrm{ppm} \\
\mathrm{R} 2=0.997\end{array}$ \\
\hline $\begin{array}{l}\text { System } \\
\text { Precision }\end{array}$ & $\% \mathrm{RSD}=0.157$ & $\begin{array}{ll}\text { \%SD } & = \\
0.157 & \end{array}$ & $\begin{array}{l}\% \text { RSD = } \\
1.182\end{array}$ \\
\hline $\begin{array}{l}\text { Intermediate } \\
\text { Precision }\end{array}$ & $\% \mathrm{RSD}=0.219$ & $\begin{array}{l}\text { \%RDD }= \\
0.189\end{array}$ & $\begin{array}{l}\% \text { RSD }= \\
0.243\end{array}$ \\
\hline $\begin{array}{l}\text { Method } \\
\text { precision }\end{array}$ & $\%$ RSD 0.354 & $\begin{array}{l}\% \text { RSD }= \\
0.145\end{array}$ & $\begin{array}{l}\% \quad \text { RSD } \\
=0.340\end{array}$ \\
\hline Accuracy & $\begin{array}{l}\% \\
\text { recovery }=100.4\end{array}$ & $\begin{array}{l}\% \text { recovery }= \\
100.4\end{array}$ & $\begin{array}{l}\% \\
\text { recovery } \\
=100.6\end{array}$ \\
\hline $\begin{array}{l}\text { Solution } \\
\text { stability }\end{array}$ & $\begin{array}{l}\text { Stable up to } 24 \mathrm{~h} \\
\% \mathrm{RSD}=1.075\end{array}$ & $\begin{array}{l}\text { Stable up to } \\
24 \mathrm{~h} \\
\% \text { RSD }= \\
0.414\end{array}$ & $\begin{array}{l}\text { Stable up } \\
\text { to } 24 \mathrm{~h} \\
\% \mathrm{RSD}= \\
0.188\end{array}$ \\
\hline
\end{tabular}

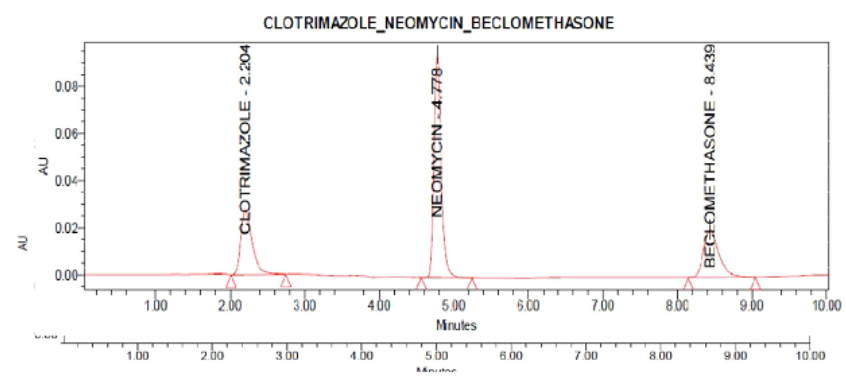

Fig 1: A representative chromatogram of standard

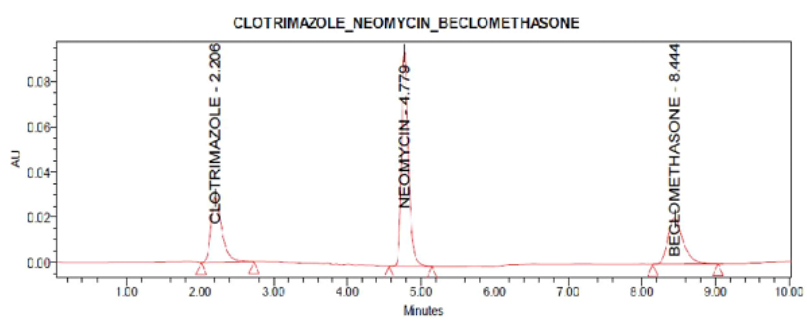

Fig. 2: A representative chromtogram of sample

\section{CONCLUSION}

In the present investigation a new analytical method was developed for potent drugs beclomethasone dipropionate, clotrimazole and neomycin sulphate. Since there is no analytical method available to estimate the combination of beclomethasone dipropionate, clotrimazole and neomycin sulphate using RP-HPLC this method will provide a choice of routine determination of beclomethasone dipropionate, clotrimazole and neomycin sulphate in bulk and pharmaceutical dosage forms.

\section{ACKNOWLEDGEMENT}

The authors are thankful to Nirmala college of pharmacy Mangalagiri, Guntur, Andhra pradesh, India for providing necessary facilities to carry out the research work.

\section{REFERENCES}

1. Komal R Dhudashia, et, al "development and validationof reversed phase of HPLC method for simultaneous estimation of clotrimazole and beclomethasone dipropionate in lotion and cream dosage form, Chronicles of Young-2013

2. Komal R Dhudashia, et.al, "simultaneous uv spectrophotometric estimation of clotrimazole and beclomethasone dipropionate in their combined dosage form by q-absorption ratio dual wave length and first order derivative method". Inventi : ppaqa/295/12 2012

3.N.B.Prajapati, ., etal "development and validation of RPHPLC for simultaneous estimation of salicylic acid and beclomethasone dipropionate in bulk and combined dosage forms", International journal of pharmaceutical research and development, IJPRD, 2013, vol 5 (3) : November-2013(041050)

4.MudduKrishna, et., al "development and validation of stability indicating methods clotrimazole and neomycin in dosage form", IJPRD, ISSN 0975-1491, vol 6, issue 1, 2014

5.. Abhishek D. Ogale, et al, "development and validation of stability indicating RP-HPLC method simultaneous estimation of beclomethasone dipropionate and clotrimazole" Eurasian journal of Analytical chemistry Vol 12 - 4/2017

6. V. Padmaja, et al "analytical method development and validation for the simutaneous estimation of beclomethasone dipropionate and clotrimazole by RP-HPLC method in bulk and pharmaceutical dosage form ". Pharma research library jan/2018.

7..G. M. Gaucher, An introduction of chromatography. Chem. Educ., 1969, 46 (11), 729.

8. M. Tswett, Bulletin de Laboratories de Botanique Générale de l'Université de Genève, 1896, 1(3), 125-206.

9. M.S. Tswett, Trudy Obshchestva Estestvoispytatelei pri Imperator ski Kazanskom University, 1901, 35(3), 1-268.

10. M.S. Tswett, Botanisches Centralblatt, 1902, 89, 120-123.

11. M.S. Tswett, Trudy Varshavskogo Obshchestva Estestvoispytatelei Otdelenie Biologii, 1905, 14, 20-39.

12. G. Hesse and H. Weil, Eds., Michael Tswett's First Paper on Chromatography, 1954.

13 V.G. Berezkin, Ed., Chromatographic Adsorption Analysis: Selected Works of M.S. Tswett, 1990. 
Indo Global Journal of Pharmaceutical Sciences, 2018; 8(3): 88-91

14. Bailey F. J Chromato. Applications of high-performance liquid chromatography in the pharmaceutical industry. 1976 July 7; 122: 73-84.

15. L.S.ETTRE, Nomenclature for Chromatography, Pure \&Appl, Chem., 1993, 65, 4, 8. 1

16. United States Pharmacopoeia Edition-30, NF-25, 621.

17. John curling, History of chromatography, Biopharm international, 2007, 1.

18. Remington, The science and practice of pharmacy by Remington, volume I, 21st edition, 2009, 599-614.

19. A Supercritical Success Story, Poliakoff M., Meehan N. J., and Ross S. K., Chemistry \& Industry 1999, 19, 750-52.

20. Li Sam. Capillary Electrophoresis: Principles, Practice, and Applications. Journal of Chromatography Library; Elsevier Science Publishers: The Netherlands, 1992; Vol 5

21. Kenneth A. Connors, A text book of pharmaceutical analysis, 3rd edition, 392-411.

22. Lloyd R.Snyder, Practical HPLC Method Development, 2nd edition, 59-100.

23. Lloyd R.Snyder, Practical HPLC Method Development, 2nd edition, 174-230.

24. Szabolcs Fekete, Jeno Fekete, Imre Molnár, Katalin Ganzler, Journal of chromatography (2009) 7816-7823.

25. Prep Star SD-1 Solvent Delivery System Operation Manual Installation Category II Pollution Degree 2 Safety Class, 2010, 6.

26. Ghulam A. Shabir, HPLC Method Development and Validation for Pharmaceutical Analysis, Mar 1, 2004.

27. Elevated Temperature HPLC: LCGC Asia Pacific, March $2005,8,1$.

28. Lloyd R.Snyder, Practical HPLC Method Development, 2nd edition, 101-170.

29. Monika Bakshi, Saranjit Singh, Development of validated stability-indicating assay methods - critical review, Journal of Pharmaceutical and Biomedical Analysis 28 (2002) 10111040.

30. Validation of analytical procedures: definition and terminology. Recommended for Implementation at Step 7 of the VICH Process on 22 October 1998 by the VICH Steering Committee.

31. Analytical Methods Validation for FDA Compliance The Center for Professional Advancement 2003, 3, 12-14.

32. The European Agency for the evolution of medicinal products, London, 1 March 200128 . Validation of compendia methods (2007) the United States Pharmacopeia, 30th edition,

33. Binns RB, Tsuji K. High-performance liquid chromatographic analysis of neomycin in petrolatum-based ointments and in veterinary formulations. J Pharm Sci. 1984
Jan;73(1):69-72.

34. http:// http://www.drugbank.ca/drugs/DB00394 35 .

http://moldb.wishartlab.com/molecules/DB00394/image.png 36. http://www.drugbank.ca/drugs/db00257

Indo Global Journal of Pharmaceutical Sciences( ISSN 22491023 ; UGC Journal No.: 44477; CODEN- IGJPAI; NLM ID: 101610675) indexed and abstracted in EMBASE(Elsevier), UGC Journal List, National Library of Medicine (NLM) Catalog, Elsevier( EMBASE), ResearchGate, Publons, CAS (ACS), Index Copernicus, Google Scholar and many more. For further details, visit http://iglobaljournal.com 